NASA/TM-2002-211327

\title{
Structural Analyses of Stirling Power Convertor Heater Head for Long-Term Reliability, Durability, and Performance
}

Gary R. Halford

Glenn Research Center, Cleveland, Ohio

Ashwin Shah

Sest, Inc., Middleburg Heights, Ohio

Vinod K. Arya

University of Akron, Akron, Ohio

David L. Krause and Paul A. Bartolotta Glenn Research Center, Cleveland, Ohio 
Since its founding, NASA has been dedicated to the advancement of aeronautics and space science. The NASA Scientific and Technical Information (STI) Program Office plays a key part in helping NASA maintain this important role.

The NASA STI Program Office is operated by Langley Research Center, the Lead Center for NASA's scientific and technical information. The NASA STI Program Office provides access to the NASA STI Database, the largest collection of aeronautical and space science STI in the world. The Program Office is also NASA's institutional mechanism for disseminating the results of its research and development activities. These results are published by NASA in the NASA STI Report Series, which includes the following report types:

- $\quad$ TECHNICAL PUBLICATION. Reports of completed research or a major significant phase of research that present the results of NASA programs and include extensive data or theoretical analysis. Includes compilations of significant scientific and technical data and information deemed to be of continuing reference value. NASA's counterpart of peerreviewed formal professional papers but has less stringent limitations on manuscript length and extent of graphic presentations.

- TECHNICAL MEMORANDUM. Scientific and technical findings that are preliminary or of specialized interest, e.g., quick release reports, working papers, and bibliographies that contain minimal annotation. Does not contain extensive analysis.

- CONTRACTOR REPORT. Scientific and technical findings by NASA-sponsored contractors and grantees.
- CONFERENCE PUBLICATION. Collected papers from scientific and technical conferences, symposia, seminars, or other meetings sponsored or cosponsored by NASA.

- SPECIAL PUBLICATION. Scientific, technical, or historical information from NASA programs, projects, and missions, often concerned with subjects having substantial public interest.

- TECHNICAL TRANSLATION. Englishlanguage translations of foreign scientific and technical material pertinent to NASA's mission.

Specialized services that complement the STI Program Office's diverse offerings include creating custom thesauri, building customized data bases, organizing and publishing research results ... even providing videos.

For more information about the NASA STI Program Office, see the following:

- Access the NASA STI Program Home Page at http://www.sti.nasa.gov

- E-mail your question via the Internet to help@sti.nasa.gov

- Fax your question to the NASA Access Help Desk at 301-621-0134

- Telephone the NASA Access Help Desk at 301-621-0390

- Write to:

NASA Access Help Desk

NASA Center for AeroSpace Information 7121 Standard Drive

Hanover, MD 21076 
NASA/TM-2002-211327

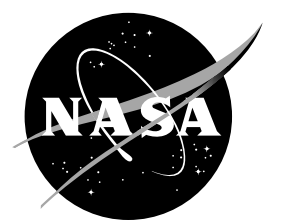

\section{Structural Analyses of Stirling Power Convertor Heater Head for Long-Term Reliability, Durability, and Performance}

Gary R. Halford

Glenn Research Center, Cleveland, Ohio

Ashwin Shah

Sest, Inc., Middleburg Heights, Ohio

Vinod K. Arya

University of Akron, Akron, Ohio

David L. Krause and Paul A. Bartolotta

Glenn Research Center, Cleveland, Ohio

Prepared for the

Space Technology and Applications International Forum (STAIF-2002)

sponsored by the American Institute of Aeronautics and Astronautics

Albuquerque, New Mexico, February 3-7, 2002

National Aeronautics and

Space Administration

Glenn Research Center 
Trade names or manufacturers' names are used in this report for identification only. This usage does not constitute an official endorsement, either expressed or implied, by the National Aeronautics and Space Administration.

Available from

NASA Center for Aerospace Information 7121 Standard Drive

Hanover, MD 21076
National Technical Information Service 5285 Port Royal Road Springfield, VA 22100

Available electronically at http://gltrs.grc.nasa.gov/GLTRS 


\title{
Structural Analyses of Stirling Power Convertor Heater Head for Long-Term Reliability, Durability, and Performance
}

\author{
Gary R. Halford \\ National Aeronautics and Space Administration \\ Glenn Research Center \\ Cleveland, Ohio 44135 \\ Ashwin Shah \\ Sest, Inc. \\ Suite 104, 18000 Jefferson Park \\ Middleburg Heights, Ohio 44130 \\ Vinod K. Arya \\ University of Akron \\ Department of Theoretical and Applied Mathematics \\ Akron, Ohio 44325 \\ David L. Krause and Paul A. Bartolotta \\ National Aeronautics and Space Administration \\ Glenn Research Center \\ Cleveland, Ohio 44135
}

\begin{abstract}
Summary
Deep-space missions require onboard electric power systems with reliable design lifetimes of up to $10 \mathrm{yr}$ and beyond. A high-efficiency Stirling radioisotope power system is a likely candidate for future deep-space missions and Mars rover applications. To ensure ample durability, the structurally critical heater head of the Stirling power convertor has undergone extensive computational analyses of operating temperatures (up to $650{ }^{\circ} \mathrm{C}$ ), stresses, and creep resistance of the thin-walled Inconel 718 bill of material. Durability predictions are presented in terms of the probability of survival. A benchmark structural testing program has commenced to support the analyses. This report presents the current status of durability assessments.
\end{abstract}

\section{Introduction}

Reliable durability along with ample functional performance must be demonstrated before long-term structural systems can be fully accepted for use. Computational analyses and long-term experimental input are essential ingredients for this. The approach taken to ensure the structural reliability, durability, and performance of a Stirling power convertor heater head is described and discussed in this report. The convertor must generate electric power with a high degree of reliability for mission durations up to $10 \mathrm{yr}$ and beyond. The structurally critical cylindrical heater head is made of thin-section wrought Inconel 718 and must operate at temperatures as high as $650^{\circ} \mathrm{C}$. Creep resistance is the dominant durability limitation.

Tradeoffs between maximum operating temperature $\left(650^{\circ} \mathrm{C}\right)$, hoop stress, and creep resistance have been examined for Inconel 718 in the conditions of proposed use. The internally pressurized cylinder (nominal $2.5 \mathrm{MPa}$ ) must not be allowed to distort excessively (or rupture) because of creep. The structural durability design criterion for the heater head is expressed as a durability surface with coordinates in 
temperature $T$, stress $\sigma$, and operational lifetime $t_{f}$. Families of nonintersecting durability surfaces reflect various probabilities of successful operation.

In support of the durability analysis activities, the NASA Glenn Research Center is generating creep and rupture data for the material with specified thickness and specific heat that is to be used in the construction of heater heads for flight convertors. A benchmark component testing program is also underway. Because of time constraints, creep testing must be restricted to no more than about a 2-yr duration, far short of the required $10 \mathrm{yr}$ or more. Fortunately, about three decades ago, an extensive longterm creep and creep-rupture data base had been generated (Brinkman, Booker, and Ding, 1991) on Inconel 718 by the Oak Ridge National Laboratories (ORNL) in support of terrestrial electric power generation. Certain aspects of their results are being used extensively in the current evaluations, namely, long-term results and measured statistical variations. The ORNL creep life data cannot be used directly because of quantifiable differences between them and preliminary NASA Glenn data resulting from slight variations in alloy chemistry and grain size. Also of importance is the significant difference in thickness of the creep test specimens used by the two laboratories. The Glenn creep test specimens were only $0.5 \mathrm{~mm}$ thick (i.e., about four to five times the diameter of a human hair). This thickness was selected to be reasonably representative of the thickness of the convertor pressure vessel enclosing the regenerator. Preliminary design calculations indicated that the maximum thickness in this area might be as small as $0.38 \mathrm{~mm}$. Based on information of the current study, however, the hot section thickness has to be increased to meet life requirements with high probabilities of success. The new thickness values under consideration range from 0.89 to $1.14 \mathrm{~mm}$. By contrast, the ORNL data (Brinkman, Booker, and Ding, $1991)$ were generated using test specimens on the order of 20 times thicker $(\approx 10 \mathrm{~mm})$ than those used by Glenn. Creep resistance for wrought alloys generally decreases dramatically with decreasing specimen thickness (below about 20 grain diam.) and with decreasing grain size. Scaling factors accounting for the differences between the ORNL and the Glenn data have been established and will be reexamined as the Glenn data base nears completion.

The heater head benchmark testing program will assess relatively short-term $(1 \mathrm{yr})$ creep growth under realistic operating conditions. The favorable, concave upward shape of the creep curve of Inconel 718 allows realistic extrapolation to longer times from short time behavior.

\section{Finite-Element Analysis}

Elastic finite-element structural and thermal analyses of the cylindrical portion of the heater head were performed using the finite-element program MARC (Anon., 1996). Appropriate boundary and symmetry conditions were applied at both ends. No credit was taken for any stiffening or strengthening imparted by either an internal or external heat-conduction structure that might increase durability.

Because of geometric symmetry, only a segment (slice) of the heater head (fig. 1) was modeled and utilized in the analysis. Thin-shell elements were employed. The tapered wall thickness of the segment was incorporated in the shell elements.

A steady mean internal pressure of $2.5 \mathrm{MPa}$ was applied to the heater head. The finite-element analysis provided stress values in excellent agreement with those obtained from considerations of the basic strength of materials equilibrium, which considers the heater head locally as a thin cylindrical shell. Effects on durability resulting from an $82-\mathrm{Hz}$ oscillating internal pressure of \pm 10 percent of the mean have been considered. However, results of detailed calculations have shown these effects to be of secondorder importance and hence are not included in the ensuing analyses.

A linear thermal conductivity analysis of the heater head was performed by employing temperature boundary conditions of $650{ }^{\circ} \mathrm{C}$ at the thicker heater end and $80{ }^{\circ} \mathrm{C}$ at the cold, thinner end. The temperature distribution over the axial length of the heater head was slightly nonlinear because of the wall thickness tapering. The temperature-dependent values of Young's modulus of elasticity $E$ and the coefficient of thermal expansion CTE for Inconel 718 used in the analyses are listed in table I. 


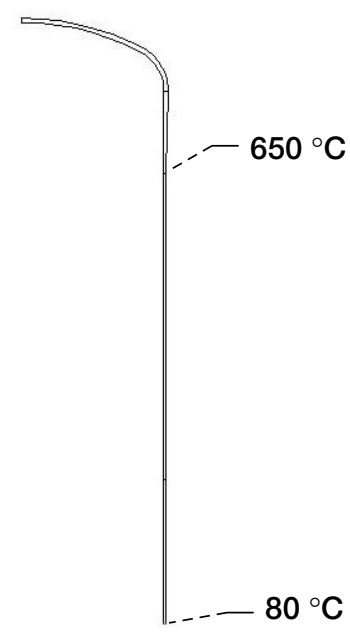

Figure 1.-Stirling heater head structural analysis segment.

TABLE I.-TEMPERATURE-DEPENDENT PROPERTIES

OF INCONEL 718

\begin{tabular}{|c|c|c|}
\hline $\begin{array}{c}\text { Temperature, } \\
{ }^{\circ} \mathrm{C}\end{array}$ & $\begin{array}{c}\text { Elastic modulus, } \\
E, \\
\mathrm{MPa}\end{array}$ & $\begin{array}{c}\text { Thermal expansion, } \\
C T E, \\
10^{-6} /{ }^{\circ} \mathrm{C}\end{array}$ \\
\hline 21 & 200 & 12.2 \\
204 & 190 & 13.3 \\
427 & 178 & 14.0 \\
538 & 171 & 14.4 \\
650 & 163 & 14.9 \\
\hline
\end{tabular}

For purposes of parametric studies, three values of the pressure vessel wall thickness at the critical hot end of the regenerator were considered: $0.89,1.02$, and $1.14 \mathrm{~mm}$. In all cases, the thickness tapered linearly to a mere $0.28 \mathrm{~mm}$ at the cold temperature end. These configurations gave rise to a range of probabilities of survival for a given mission usage.

\section{Creep Characterization}

The generation of sufficient long-term $\left(>10^{4} \mathrm{~h}\right)$, high-temperature creep data for engineering alloys is a formidable and time-consuming task. It is expensive because of the duration of testing and the range of variables to be covered. Many tests under different temperature and stress conditions generally are required for numerous heats of a material to determine general creep and creep-rupture laws describing the behavior. Also, large numbers of these tests are required because of the significant scatter typically observed in creep and creep-rupture testing.

Because of cost and time constraints, large data bases for long-term creep and creep-rupture behavior are rarely generated. Current industrial practice is to perform accelerated creep tests and extrapolate the results to approximate long-term behavior using what are known as time-temperature parameters, the most common being the classical Larson-Miller parameter (1952). As discussed below, we have not had to resort to such extrapolation methods because of the existence of a large data base for Inconel 718 .

In an effort to develop a suitable creep durability model for analyses of the heater head, an engineering methodology has been adopted. It utilizes the large creep data base generated by ORNL (Brinkman, Booker, and Ding, 1991) for various heats, heat treatments, and product forms of Inconel 718. Although there are differences between the material used for the ORNL tests and that to be used in the 
current heater head, the proposed methodology captures the differences and accounts for their effect on creep behavior. The following paragraphs provide details of the analyses of the ORNL data and a description of the methodology for the material to be used for the heater head.

The ORNL test data encompass 14 heat forms of bar, plate, and forged material over the temperature range 538 to $704{ }^{\circ} \mathrm{C}$. The longest reported rupture life is $87000 \mathrm{~h}(10 \mathrm{yr})$. The data cover the pertinent temperature and time regimes of the heater head design. The Glenn heater head test material is only about 5 percent of the thickness of the ORNL test material. As described in the Introduction, the creep behavior of this material could be appreciably different from that of the ORNL material. Measures have been taken to evaluate correlation constants for the Glenn creep data with respect to those reported by ORNL. The methodology focuses on adopting the ORNL master curve model (eq. (1)). This model is thoroughly explained by Brinkman, Booker, and Ding (1991):

$$
e^{*}=\exp \left[\beta\left(t^{*}-1\right)\right]\left(t^{*}\right)^{\alpha}
$$

where $e^{*}$ is the normalized creep strain (with respect to creep strain at the onset of tertiary creep), $t^{*}$ is the normalized time (with respect to time at the onset of tertiary strain), and $\alpha$ and $\beta$ are constants quantified from test data.

The stress and temperature independence of the general form of equation (1) over the temperature range up to $650{ }^{\circ} \mathrm{C}$ makes it generic in terms of its application. Constants in the equation had been evaluated by ORNL using nonlinear regression analysis. These data were further analyzed to quantify their statistical distribution and scatter in the magnitude of the constants. It should be noted that scatter in the ORNL results is assessed independently of the product form and other variables. Hence, it is reasonable to take advantage of the large data base generated by ORNL to approximate the scatter in the relatively small amount of data that will be generated in the limited-time Glenn program. The ORNL creep-rupture law (eq. (2)) has been applied directly to the existing Glenn results on the heater head material by adjusting only the heat constant $C_{h}$, giving rise to rupture lives

$$
\log \left(t_{r}\right)=C_{h}+C_{1} \log \sigma+C_{2}(\log \sigma)^{2}+C_{3}(\log \sigma)^{3}+C_{4} T \log \sigma
$$

where $t_{r}$ is rupture life in hours, $C_{h}, C_{1}, C_{2}, C_{3}$, and $C_{4}$ are the constants determined from the ORNL data (for Inconel 718, $C_{h}=162.319, C_{1}=-193.662, C_{2}=88.117, C_{3}=-12.807$, and $C_{4}=-0.01052$ ), $\sigma$ is stress in megapascals, and $T$ is temperature in kelvin.

These rupture lives are, at worst, one-third of those from ORNL for the same stress and temperature. As more Glenn data are generated, this factor of one-third could change. This difference in rupture lives reflects the combined effects of specimen thickness, chemistry, and grain size governed by the heat treatment. Note that the limited Glenn data are based on creep tests at higher stresses (and shorter times to rupture) than anticipated in the actual design. Therefore, the Glenn results must be extrapolated to the lower stress, longer life regime. Using the rupture life variation pattern at the higher stresses, the Glenn results are extrapolated parallel in life to those from ORNL. Once the rupture life from equation (2) is calculated, equation (1) can be used for determining the creep strain behavior. Thus, the rupture life is downscaled to give an estimation of the time to the onset of the tertiary creep. Based on the ORNL data, the scale factor for the time to reach tertiary creep $t_{t e r}$ is approximately 70 percent of the rupture life $t_{r}$. The design time to failure is defined as $t_{f}$, where $t_{f} \equiv t_{t e r}$. The selection of the tertiary creep strain as the criterion for design lifetime was based on two important considerations: First, it places a deformation limit on the cylindrical section of the heater head that prevents the wall from growing excessively, and second, this measure of strain was fortunately well documented by ORNL. Equation (1) resulted from the recorded data. 


\section{Design Criteria and Probabilistics}

Considerable scatter is generally observed in both creep rate and creep-rupture life data. The reliable design of high-temperature structural components subject to creep becomes complicated because of these uncertainties. Conventional deterministic design approaches use sizeable knockdown safety factors to ensure adequate durability. This usually results in overly conservative and heavy designs. Since spacebased power conversion systems generally cannot tolerate excess weight, a rational alternative to deterministic design is required. Fortunately, uncertainties in material behavior as well as any design variables can be rationally accounted for using a probabilistic approach.

This long-range probabilistic approach for the heater head analysis aims at quantifying the uncertainties in the constants in equations (1) and (2) and adopting a Monte-Carlo simulation to perform probabilistic creep and creep-rupture durability analyses. The methods of most likelihood event (MLE) and least squares will be combined to quantify the uncertainties in the constants. Since sufficient data for the Glenn heater head material are not available, the uncertainties in the ORNL data have been quantified and applied to the Glenn heater head material. ORNL test data covering stress values from 170 to $1096 \mathrm{MPa}$ and temperatures from 538 to $704{ }^{\circ} \mathrm{C}$ were fit to a Weibull distribution using the MLE method. Figure 2 shows the cumulative probability distribution of the ORNL test data (in unit normal space) and the analytic Weibull distribution of these data. Note that the rupture life has been represented as a ratio of observed rupture life to the mean rupture life. The quantified mean value of the ratio is 1.57 , and the scatter is 91 percent. Since the analytically obtained probability distribution curve matches fairly well with the test data, it is used to compute the life for a desired probability of survival.

Three-dimensional probabilistic durability surfaces (stress, temperature, and design time to failure) for ranges of reliability have been generated. An example durability surface for 50-percent probability of survival (PoS) for extrapolated creep-rupture life for the ORNL data is shown in figure 3. The durability surface is shaded with patterns to show various combinations of temperature and stress that result in the range of life represented by a specific shade. Families of nominally parallel surfaces (parallel relative to the time axis) would represent various levels of PoS.

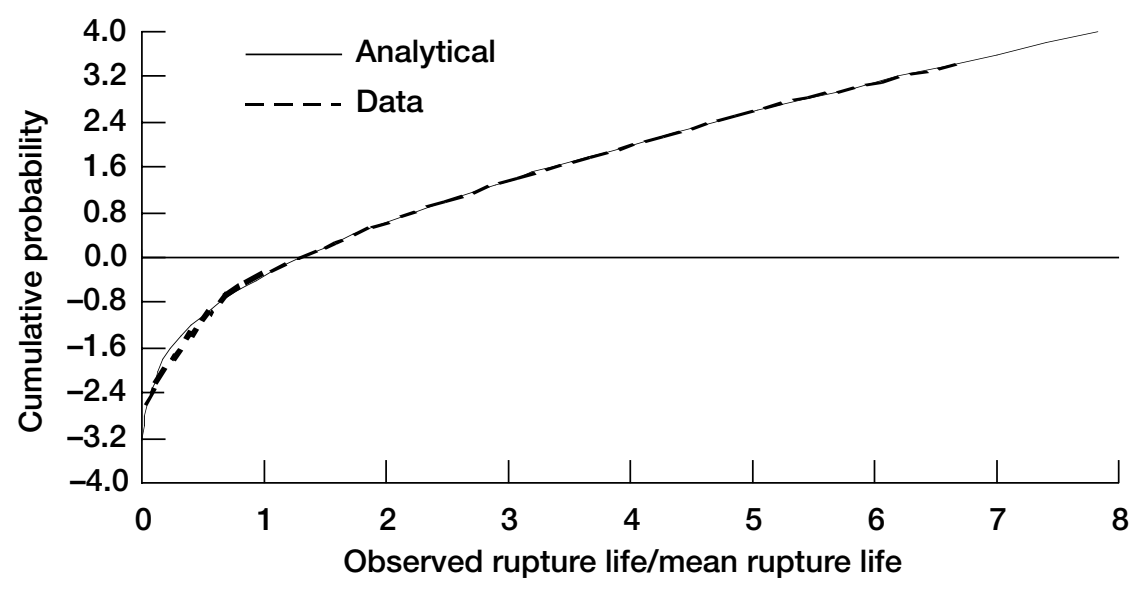

Figure 2.-Probability distribution (in unit normal space) of the rupture life, ORNL data with stresses of 170 to $1096 \mathrm{MPa}$ and temperatures from 538 to $704^{\circ} \mathrm{C}$. 


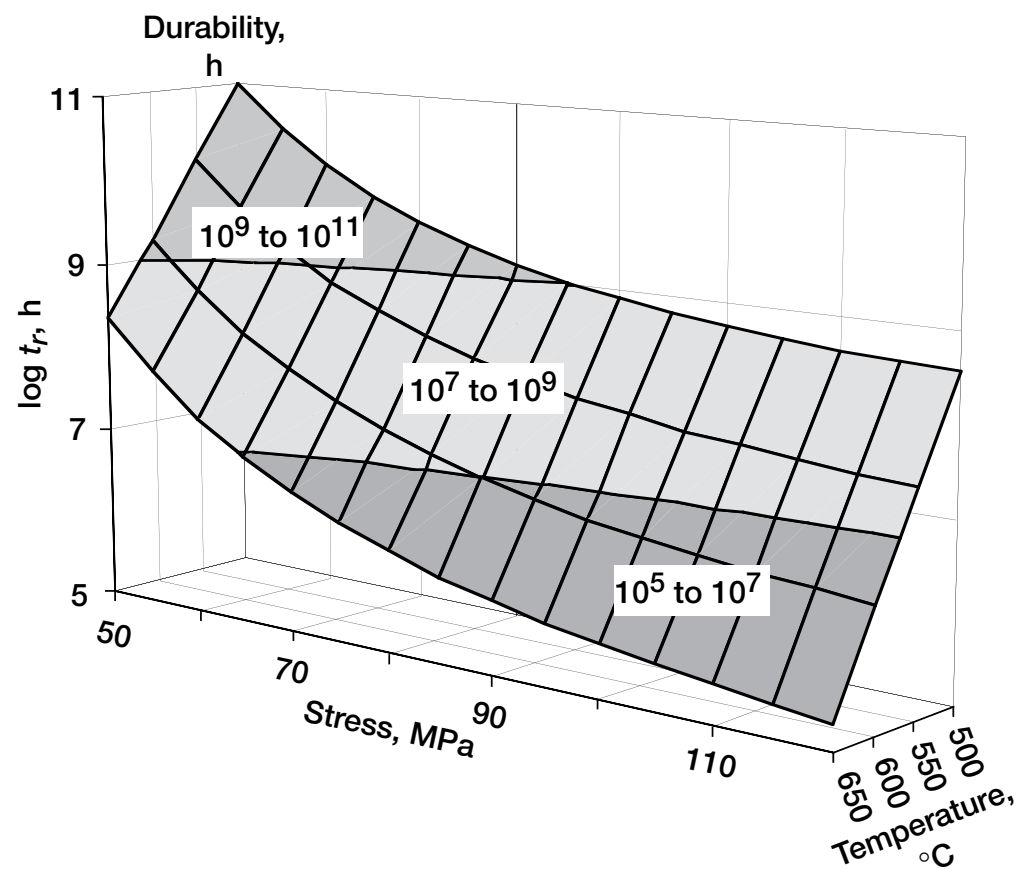

Figure 3.-Failure surface for 50-percent PoS. Extrapolated time to rupture, $t_{r}$.

TABLE II.-FACTORS OF SAFETY ON CALCULATED ALLOWABLE LIFETIME RELATIVE TO $100000 \mathrm{~h}$ FOR VARIOUS PROBABILITIES OF SURVIVAL

\begin{tabular}{|c|c|c|c|}
\hline \multirow{2}{*}{$\begin{array}{c}\text { Probability } \\
\text { of survival, } \\
\text { percent }\end{array}$} & \multicolumn{3}{|c|}{ Factors of safety } \\
\cline { 2 - 4 } & 0.89 & 1.02 & 1.14 \\
\hline 50 & 13 & 52 & 230 \\
90 & 5 & 5 & 93 \\
99 & 1.2 & 1 & 21 \\
99.9 & 0.2 & 0.2 & 4 \\
99.99 & 0.05 & \\
\hline
\end{tabular}

The factors of safety on design lifetime are indicated in table II for the three maximum wall thickness values (of the pressure vessel enclosing the regenerator) considered. The factor of safety is expressed as the ratio of the calculated lifetime to the desired lifetime of $100000 \mathrm{~h}$ for PoS of 50, 90, 99, 99.9, and 99.99 percent for a constant use temperature of $650{ }^{\circ} \mathrm{C}$ and internal pressure of $2.5 \mathrm{MPa}$.

A lifetime ratio $>1.0$ satisfies the design lifetime requirement. The maximum thickness of $1.14 \mathrm{~mm}$ is required for the highest PoS shown, whereas a wall thickness of only $0.89 \mathrm{~mm}$ would be ample for a lower PoS of only 99 percent. The difference in weight between the two configurations is only about $25 \mathrm{~g}$ and has a negligible impact on the overall weight of the Stirling power convertor system. The greatest thickness also has only a small impact on the operating efficiency of the system.

To compare the lifetime results of table II to more traditional stress-based evaluations of PoS, it is necessary to transform the variables. Graphically, this is straightforward. First, examine the failure surface in figure 3 (shown only for 50 percent PoS) and add the other four failure surfaces for the higher percentages of PoS. Then take the two-dimensional slice of computed lifetime versus stress at a constant temperature of $650{ }^{\circ} \mathrm{C}$. One thus obtains a series of five nonintersecting curves that represent the tradeoff between life and stress at $650{ }^{\circ} \mathrm{C}$. For a constant lifetime of, say, $100000 \mathrm{~h}$, a horizontal line has five intersection points with the five PoS curves. These intersection points identify the critical stress values for 


TABLE III.-FACTORS OF SAFETY ON CALCULATED
CRITICAL STRESS FOR VARIOUS PROBABILITIES
OF SURVIVAL AT $650{ }^{\circ} \mathrm{C}$
\begin{tabular}{|c|c|c|c|}
\hline Probability & \multicolumn{4}{|c|}{ Factors of safety } \\
\cline { 2 - 4 } of survival, \\
percent & \multicolumn{3}{|c|}{ Maximum thickness, mm } \\
\hline 50 & 1.69 & 1.02 & 2.0 \\
90 & 1.2 & 1.4 & 1.6 \\
99 & 1.0 & 1.2 & 1.3 \\
99.9 & 0.9 & 1.0 & 1.1 \\
99.99 & 0.8 & 0.9 & 1.0 \\
\hline
\end{tabular}

the five PoS values. If each critical stress is normalized to the stress existing at the thickest section of the pressure vessel enclosing the regenerator $\left(\right.$ at $650{ }^{\circ} \mathrm{C}$ ), one obtains the safety factor for the stress needed to achieve the PoS desired. Results are summarized in table III. Note that for 50 percent PoS, the factor of safety for stress ranges from 1.6 to 2.0, depending upon thickness.

The proposed durability assessment methodology described above is straightforward and does not assume a specific underlying probability distribution. It is devoid of the convergence problems associated with highly nonlinear-behaving durability response surfaces and time-dependent reliability algorithms. The curves also identify the magnitudes of stress and temperature for a desired life. Thus, it could be used for design iterations to optimize and improve a given design. The resultant methodology, although currently lacking sufficient intermediate-term creep characteristics of the thin Glenn heater head material, promises a workable approach for evaluating design tradeoffs between temperature, stress, and useful lifetime with assured reliability.

A full probabilistic analysis of the critical factors governing the design life of the heater head is not as yet available. In fact, such an analysis could be misleading in the absence of accurate and pertinent information. An appropriately thorough assessment must await the more complete evaluation of the creep and creep-rupture properties of the specific Glenn material. Another year of coupon and benchmark testing is awaiting completion. In addition, procedures and techniques are being evaluated for application as further information becomes available. Additional reviews are to be held prior to finalizing important details of the heater head design. Clearly, however, relatively small additions of material to increase wall thickness in critical locations or even small percentage decreases in operating temperature can have a profound influence on increasing the reliability of a given mission lifetime. An easily remembered tradeoff is that at a given value of PoS and stress, a $15^{\circ} \mathrm{C}$ temperature change causes the creep life to change by a factor of 2 . Other tradeoffs between life, temperature, stress, and PoS can be assessed from the family of computed failure surfaces similar to the single surface shown in figure 3.

Armed with the information now available, it is also possible to assess a nonsteady mission loading history. For example, one could assess the impact on usable durability of a decreasing temperature of the heater head with time reflecting a realistic radioisotope decay process. Preliminary calculations by the authors reflect an approximate order-of-magnitude increase in life with an exponential temperature decrease of $100^{\circ} \mathrm{C}$ over a 10 -yr span.

\section{Benchmark Structural Testing}

A series of experimental benchmark tests of the heater head are planned to corroborate the structural analyses and independently determine creep performance of this component under the design loading conditions. This testing is important because predictions of creep strain in general are based on material properties determined from uniaxial creep testing. Both the ORNL historical data and the current NASA creep data are from uniaxial tests. However, the heater head configuration and pressure loading result in a 2:1 biaxial stress state, and the effects of this condition will be captured in the benchmark tests. 
The benchmark test program includes a first phase of evaluating a prototype heater head (fig. 4) at several combinations of temperature and pressure that result in creep strains representing 1,3 , and 6 months of accelerated creep deformation. These results will be employed in the analyses to more accurately predict creep behavior. The second phase of testing applies the design pressure (2.5 MPa) and temperature gradient (peaking at $650{ }^{\circ} \mathrm{C}$ ) to the benchmark heater head for $1 \mathrm{yr}$ or longer. A decision is to be made later as to whether a constant temperature or a programmed decreasing temperature history profile is used. Creep deformations will be recorded periodically, and an evaluation of experimental and analytically predicted values will be performed. This study will then result in the final prediction of the creep life under mission conditions for a 10-yr duration.

The experimental equipment includes benchtop hardware mounted with temperature-control and gas pressurization systems. The prototype test hardware is attached to a water-cooled stainless steel mounting flange that has been machined with a metal O-ring groove and threaded holes to match the cold flange. The heating system consists of a 4.5-kVA induction heater with water-cooled copper coils designed to provide the correct temperature gradient throughout the part. The pressurization system includes a regulated highpressure supply of purified argon gas, a solenoid valve, a direct drive control valve, a proportional pressure relief valve, the connecting tubing, and gas passageways machined into the mounting flange. An alumina volume fill plug is located inside the test cylinder to aid in control of gas pressurization.

A customized digital control system provided by McGaw Technology, Inc., controls pressurization and records experimental data. The control system also provides ramping, mean pressure and alternating pressure cycles, and synchronized thermal cycles, if needed, for any future test requirement. The instrumentation consists of thermocouples to measure metal temperature gradients and monitor argon temperature; a pressure transducer to control gas pressure; and strain gages to acquire initial mechanical pressure strains at room temperature. Creep deformation at the cylinder-head juncture and at the head centerline is continuously monitored with five linear variable differential transformers.

At the present time all test hardware is assembled, and nonintegrated initial testing of the induction heater and the argon system is complete. A geometrically simplified demonstration specimen has been fabricated and is currently being used to verify the performance of the entire test and data acquisition system.

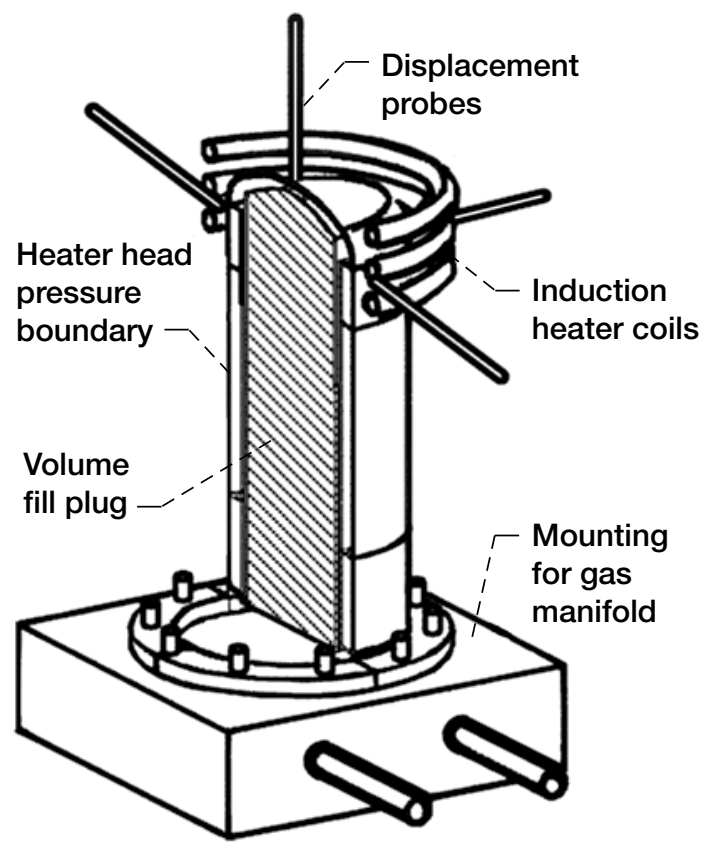

Figure 4.-Benchmark testing hardware. 


\section{Concluding Remarks}

Preliminary durability analyses emphasizing the probability of survival have been performed to assess the potential capabilities of a Stirling power convertor heater head design for long-term space science missions (deep-space and Mars rover applications). Mission lifetimes of $100000 \mathrm{~h}$ appear achievable with Inconel 718 utilized in thin sections with the maximum thickness of the pressure vessel enclosing the regenerator in the range of 0.89 to $1.14 \mathrm{~mm}$ at temperatures as high as $650{ }^{\circ} \mathrm{C}$. Confidence in the calculated probabilities of survival is currently low, as a very small amount of hardware-specific material creep data have been generated in the limited time span available to date. Nevertheless, identified trends in the influence of critical factors such as temperature and stress are now usable as valuable input to finalizing the optimal heater head design for performance and reliable durability.

\section{References}

1. Bowman, Randy R.: Long-Term Creep Assessment of a Thin-Walled Inconel 718 Stirling Power-Convertor Heater Head. Intersociety Energy Conversion Engineering Conference Paper IECEC2001-CT-33, 2001, pp. 435-440.

2. Brinkman, C.R.; Booker, M.K.; and Ding, J.L.: Creep and Creep-Rupture Behavior of Alloy 718. Proceedings of the International Symposium on the Metallurgy and Applications of Superalloys 718, 625, and Various Derivatives, Minerals, Metals \& Materials Society, Warrendale, PA, 1991.

3. Larson, F.R.; and Miller, James: A Time-Temperature Relationship for Rupture and Creep Stresses. Trans. ASME, vol. 74, pp. 765-775. 
Public reporting burden for this collection of information is estimated to average 1 hour per response, including the time for reviewing instructions, searching existing data sources, gathering and maintaining the data needed, and completing and reviewing the collection of information. Send comments regarding this burden estimate or any other aspect of this collection of information, including suggestions for reducing this burden, to Washington Headquarters Services, Directorate for Information Operations and Reports, 1215 Jefferson Davis Highway, Suite 1204, Arlington, VA 22202-4302, and to the Office of Management and Budget, Paperwork Reduction Project (0704-0188), Washington, DC 20503.

\begin{tabular}{|l|l|l}
\hline 1. AGENCY USE ONLY (Leave blank) & $\begin{array}{c}\text { 2. REPORT DATE } \\
\text { April } 2002\end{array}$ & $\begin{array}{r}\text { 3. REPORT TYPE AND DATES COVERED } \\
\text { Technical Memorandum }\end{array}$ \\
\hline
\end{tabular}

4. TITLE AND SUBTITLE

5. FUNDING NUMBERS

Structural Analyses of Stirling Power Convertor Heater Head for Long-Term

Reliability, Durability, and Performance

6. AUTHOR(S)

Gary R. Halford, Ashwin Shah, Vinod K. Arya, David L. Krause,

and Paul A. Bartolotta

7. PERFORMING ORGANIZATION NAME(S) AND ADDRESS(ES)

National Aeronautics and Space Administration

John H. Glenn Research Center at Lewis Field

Cleveland, Ohio 44135-3191

WU-896-50-10-00

9. SPONSORING/MONITORING AGENCY NAME(S) AND ADDRESS(ES)

National Aeronautics and Space Administration

Washington, DC 20546-0001

8. PERFORMING ORGANIZATION

REPORT NUMBER

E-13136

10. SPONSORING/MONITORING

AGENCY REPORT NUMBER

NASA TM-2002-211327

11. SUPPLEMENTARY NOTES

Prepared for the Space Technology and Applications International Forum (STAIF-2002) sponsored by the American Institute of Aeronautics and Astronautics, Albuquerque, New Mexico, February 3-7, 2002. Gary R. Halford, David L. Krause, and Paul A. Bartolotta, NASA Glenn Research Center; Ashwin Shah, Sest, Inc., 18000 Jefferson Park, Suite 104, Middleburg Heights, Ohio 44130; and Vinod K. Arya, University of Akron, Department of Theoretical and Applied Mathematics, Akron, Ohio 44325. Responsible person, Gary R. Halford, organization code 5000, 216-433-3265.

\begin{tabular}{|l|l}
\hline 12a. DISTRIBUTION/AVAILABILITY STATEMENT & 12b. DISTRIBUTION CODE
\end{tabular}

Unclassified - Unlimited

Subject Category: 39

Distribution: Nonstandard

Available electronically at http://gltrs.grc.nasa.gov/GLTRS

This publication is available from the NASA Center for AeroSpace Information, 301-621-0390.

13. ABSTRACT (Maximum 200 words)

Deep-space missions require onboard electric power systems with reliable design lifetimes of up to $10 \mathrm{yr}$ and beyond. A high-efficiency Stirling radioisotope power system is a likely candidate for future deep-space missions and Mars rover applications. To ensure ample durability, the structurally critical heater head of the Stirling power convertor has undergone extensive computational analyses of operating temperatures (up to $650{ }^{\circ} \mathrm{C}$ ), stresses, and creep resistance of the thin-walled Inconel 718 bill of material. Durability predictions are presented in terms of the probability of survival. A benchmark structural testing program has commenced to support the analyses. This report presents the current status of durability assessments.

\begin{tabular}{|c|c|c|}
\hline \multicolumn{3}{|c|}{$\begin{array}{l}\text { Structural analysis; Structural durability; Stirling engine; Creep; Creep-rupture; } \\
\text { Life prediction; Inconel } 718\end{array}$} \\
\hline $\begin{array}{l}\text { 17. SECURITY CLASSIFICATION } \\
\text { OF REPORT }\end{array}$ & $\begin{array}{l}\text { 18. SECURITY CLASSIFICATION } \\
\text { OF THIS PAGE }\end{array}$ & $\begin{array}{l}\text { 19. SECURITY CLASSIFICATION } \\
\text { OF ABSTRACT }\end{array}$ \\
\hline Unclassified & Unclassified & Unclassified \\
\hline
\end{tabular}

NSN 7540-01-280-5500

15. NUMBER OF PAGES

16. PRICE CODE

20. LIMITATION OF ABSTRACT

Standard Form 298 (Rev. 2-89)

Prescribed by ANSI Std. Z39-18 298-102 

